\title{
水で飽和されたモルタルの圧縮破壊および 疲労特性に関する基礎的研究

\author{
A FUNDAMENTAL STUDY OF FAILURE AND FATIGUE \\ OF MORTAR IN WATER
}

\author{
田 政 範* - 島 田 静 雄** \\ By Cheong-Beom CHEON and Shizuo SHIMADA
}

\section{1. まえがき}

コンクリートは，巨視的にみると，セメント，砂，砂 利の 3 つの相からなり，これらに水を含めていくつかの 微視的な相が加わってできた集合体であると考えられる が，そのために，コンクリートの強度および変形特性は これらの各成分に依存し, また, それらの成分によって 形成される内部組織の特徵に深い関係があるものと思わ れる.

とりわけ，鋼などと比較して，コンクリートのきわだ った組成的特徴を指摘するならば，その内部に多量の空 隚と水分を含んでいるといらことであろら．また，この 空隙は，実際に水中に置かれるコンクリート構造物を考 えると, コンクリートの空隚は水中において多量の水分 によって満たされていると考えられる.このような水に よって空隚が満たされた（あるいは水で飽和された）コ ンクリートは, そうでない場合と比較して異なった力学 的挙動を示すことが予想されるが，このような飽和水に 注目した研究はほとんどみられない。ところが実際に， コンクリート橋脚のように，一部が水中に没している圧 縮材では, 同一部材でありながら上下が異なった環境に あり, 強度および変形の性質が異なることは設計上も重 要な問題になることが考えられる.

筆者らは, コンクリートの空中・水中の二種の環境が コンクリートのカ学的挙動におよぼす影響を調べるため に, モルタル円柱供試体を使って基礎的な実験を試み た. 実験の方法は二種に大別され，一つは定荷重速度圧 縮試験（これを静的試験とよぶ）および低周期繰り返し 圧縮試験（これを繰り返し試験とよぶ）である.

実験結果の検討にあたっては, 応力ーひずみ一時間関係 つまり粘弾性的挙動（レオロジー）に注目するように整

* 正会員 工修 名古屋大学工学部土木学科 研究生

** 正会員 工博 名古屋大学助教授 工学部土木工学科
理し, 静的試験におけるモルタルの破壊（静的破壊）と 繰り返し試験における破壊（疲労破壊）とが同じ理論モ デルで説明できるような破損条件を提案した.

\section{2. 実験方法}

\section{（1）供 試 体}

静的試験と繰り返し試験に使用した供試体は, 直径 $10 \mathrm{~cm}$, 高さ $20 \mathrm{~cm}$ の円柱形で, 材料は普通ポルトラン ドセメントと粒径 $5 \mathrm{~mm}$ 以下の川砂を Table 1 に示す ように配合したモルタルである。

Table 1 Mix-Proportion of Mortar

\begin{tabular}{c|c|c|c|c|c}
\hline \multirow{2}{*}{$\begin{array}{c}\text { Max. Size } \\
(\mathrm{mm})\end{array}$} & \multirow{2}{*}{$\begin{array}{c}\text { Flow } \\
(\mathrm{mm})\end{array}$} & $\begin{array}{c}W / C \\
(\%)\end{array}$ & \multicolumn{3}{|c}{$\begin{array}{c}\text { Weight of Unit Volume } \\
\left(\mathrm{kg} / \mathrm{m}^{3}\right)\end{array}$} \\
\hline $\mathbf{5}$ & $180 \pm 5$ & 55 & 300 & 545 & 1342 \\
\hline
\end{tabular}

供試体の打込みは, 実験設備の都合で 5 バッチに分け て行った. 打込み後 24 時間で脱型し, 材令 28 日まで水 中で, その後材令 100 日まで空中 (水温・室温 $21 \pm 3^{\circ} \mathrm{C}$, $\mathrm{RH} \doteqdot 90 \%)$ で養生して, 特に水中で試験を行う供試体 は試験する 7 日前に水中に戻すよ5にした。

また, モルタルの物理的性質, すなわち比重, 空隚 率, 吸水率を知るために, 供試体の水中重量, 表面乾燥 重量, 絶対乾燥重量を測定した.ただし, 水中重量とは 供試体を水中に浸した状態の重量 $\left(W_{w}\right)$ で, 表面乾燥 重量とは水中から取出したばかりの供試体の表面を布で ふいて表面の水膜を取除いた状態の重量 $\left(W_{a}\right)$ で, 絶 対乾燥重量とは電気乾燥炉にて $110^{\circ} \mathrm{C}$ でほぼ 3 日間乾燥 させた状態の重量 $\left(W_{d}\right)$ である. また, 十分に炉乾燥 したモルタルを乳ばちで完全に粉砕し, 細骨材の比重試 験に準じた方法によって測定した比重をモルタルの真比 重 $\left(r_{m}\right)$ とする. 
Table 2 Physical Properties of Mortar Specimens

\begin{tabular}{|c|c|c|c|c|c|c|c|c|}
\hline $\begin{array}{c}\text { Number } \\
\text { of } \\
\text { Batch }\end{array}$ & $\begin{array}{l}\text { Gravity of } \\
\text { Air-dry } \\
100 \text { days } \\
\text { (g) }\end{array}$ & $\begin{array}{l}\text { Gravity of } \\
\text { Sur.-dry } \\
28 \text { days } \\
\text { (g) }\end{array}$ & $\begin{array}{c}\text { Gravity of } \\
\text { Sur.-dry } \\
100 \text { days } \\
W_{b}(\mathbf{g})\end{array}$ & $\begin{array}{c}\text { Gravity in } \\
\text { Water } \\
100 \text { days } \\
W_{c}(\mathrm{~g})\end{array}$ & $\begin{array}{c}\text { Volume } \\
\begin{array}{c}V=W_{b}-W_{c} \\
\left(\mathrm{~cm}^{3}\right)\end{array}\end{array}$ & $\begin{array}{c}\text { Specific } \\
\text { Gravity } \\
W_{b} / V\end{array}$ & $\begin{array}{c}\text { Absorption } \\
\left(W_{b}-W_{a}\right) / W_{a} \\
(\%)\end{array}$ & $\begin{array}{c}\text { Porosity } \\
\left(V-\frac{W_{a}}{2.52}\right) / V \\
(\%)\end{array}$ \\
\hline 1 & 3315 & 3373 & 3359 & 1797 & 1562 & 2.15 & 11.0 & 23.2 \\
\hline 2 & 3289 & 3358 & 3334 & 1772 & 1562 & 2.13 & 10.2 & 23.2 \\
\hline 3 & 3317 & 3386 & 3377 & 1813 & 1564 & 2.16 & 11.6 & 23.2 \\
\hline 4 & 3308 & 3375 & 3361 & 1796 & 1565 & 2.15 & 11.1 & 23.3 \\
\hline 5 & 3280 & 3349 & 3339 & 1773 & 1567 & 2.13 & 10.4 & 23.4 \\
\hline Average & 3302 & 3368 & 3354 & 1790 & 1564 & 2.15 & 10.9 & 23.3 \\
\hline
\end{tabular}

Table 3 Compressive Strength of Mortar at Age of 28 days

\begin{tabular}{c|c|c|c|c|c}
\hline Batch & 1 & 2 & 3 & 4 & 5 \\
\hline \multirow{3}{*}{$\sigma_{28}\left(\mathrm{~kg} / \mathrm{cm}^{2}\right)$} & 312 & 322 & 268 & 341 & 266 \\
& 299 & 285 & 255 & 316 & 326 \\
& 316 & 305 & 325 & 341 & 312 \\
\hline Ave. & 309 & 304 & 282 & 333 & 301 \\
\hline
\end{tabular}

Table 4 Analysis of Variancies of Compressive Strength of Mortar at Age of 28 days

\begin{tabular}{|c|c|c|c|c|}
\hline & $\mathrm{df}$ & ss & $\mathrm{ms}$ & $F$ \\
\hline Between & 4 & 3944 & 986 & \multirow{3}{*}{$\begin{aligned} 1.64 & <{ }_{95} F_{10}{ }^{4} \\
& =3.48\end{aligned}$} \\
\hline Within & 10 & 6008 & & \\
\hline Total & 14 & 9872 & & \\
\hline
\end{tabular}

Table 5 Compressive Strength Mortar at Age of 100 days

\begin{tabular}{c|c|c}
\hline & Air & Water \\
\hline & 407 & 360 \\
& 409 & 390 \\
$\sigma_{100}\left(\mathrm{~kg} / \mathrm{cm}^{2}\right)$ & 416 & 364 \\
& 430 & 355 \\
& 400 & 346 \\
& 409 & 374 \\
\hline Ave. & 412 & 365 \\
\hline
\end{tabular}

すなわち, 供試体の比重 $(\gamma)$, 空幥率 $(p)$, 吸水率 ( $w)$ を次式のように表わすことにする.

$$
\left.\begin{array}{ll}
\text { 比 重 } & r=W_{a} /\left(W_{a}-W_{w}\right) \\
\text { 空隙率 }(\%) & p=100\left(V-W_{d} / \gamma_{m}\right) / V \\
\text { 吸水率 }(\%) & \omega=100\left(W_{a}-W_{d}\right) / W_{d}
\end{array}\right\}
$$

\section{ここに, $V$ : 供試体のみかけの体積 $\left(W_{a}-W_{w}\right)$}

式 (1) で表わされる物理的性質および材令 28 日, 100 日の压縮強度, また, バッチ間の強度のばらつきを 分散分析によって検定した結果などを Table 2 5 亿示 す.

\section{（2）測定方法}

供試体への載荷は, $100 \mathrm{t}$ 万能試験機（島津 $\mathrm{RH}-100$ 型）および自動負荷制御装置によって, 荷重速度を一定 に制御して行った。 また, 水中における供試体一の載荷

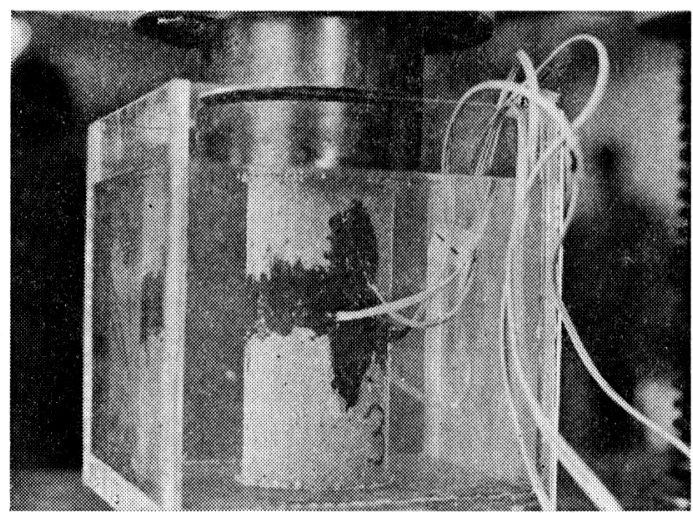

Photo. 1 Method of Loading in Water

方法は，底板が鋼でできたアクリル樹脂容器に水を満た して，この中で荷重を加えるように工夫した（Photo1 参照).

ひずみの測定は，供試体の側面の相対する中央 2 䇫所 に, 電気低抗線ひずみゲージ（共和 KC-70-A 1) を接 着剤 (PC 12, CC 15) によって張り付け, 特に, 水中の 供試体に対しては防水性・絶縁性を考えて十分にコーテ ィングを行った、ひずみの記録は，荷重速度が比較的速 い場合を対象にしていること，また，応力ーひずみ一時間 関係，特に破壊付近の様子を正確に知りたいことから， データーレコーダ (共和 RTP-100 A 型)，ストレイン アンプ (三栄 W.613-試作型), オッシログラフ (三栄 FR-102 型) などの電子計測機器を使用して行った.

こうして, 静的試験は，5種類の荷重速度（それぞれ 毎秒 $\left.0.166,2.49,4.97,9.94,19.88 \mathrm{~kg} / \mathrm{cm}^{2}\right)$ につい て，それぞれ 3 4 個ずつの合計 35 個の供試体に対し て, 一方, 繰り返し試験は, 静的試験の 5 種類の荷重速 度のらち毎秒 $19.88 \mathrm{~kg} / \mathrm{cm}^{2}$ を除いた他の 4 種類につい て, また，空中あるいは水中の圧縮強度の 80 および 90 \%を上限とする荷重振幅について, 合計 25 個の供試体 に対して行った. 特に, 繰り返し試験の一部の供試体に ついては, 超音波伝播速度測定器 (開発電子測器 SLS 1002-D 型) によって, 疲労に伴ら内部損傷の累積の様 子を検討した。 


\section{3. 実験結果と考察}

\section{（1）単軸圧縮応力-軸ひずみ一時間の関係}

1) 圧縮強度，最大圧縮ひずみ，ヤング係数

静的圧縮荷重下の軸ひずみと横ひずみをオッシログラ フに再生した結果の一例を Fig. 1 に示す.これから， 応力ーひずみー時間の相互の関係を読み取り整理した.

圧縮強度 $\left(\sigma_{u}\right)$ と破壊に至るまでの要した時間（破壊 時間 $t_{u}$ ) との関係は, Fig. 2 に示すように, 相関性が あると考えられる．この場合の実験式は Table 6 の式 （1）に示す. ここに，実験式を求める際には直交多項 式による回帰分析を行っで ${ }^{1)}$, 物理量の間の相関性を検 定して判断の目安とした. その際, 一部のものについて は萧却されたものもあったが, 空中と水中との比較のた めにあるいは図から直接判断して実験式を求めた. ま た, Table 6 の左側は空中の場合で, 右側が水中の場 合であり, 式の番号に付記した（a) は空中, (w) は水

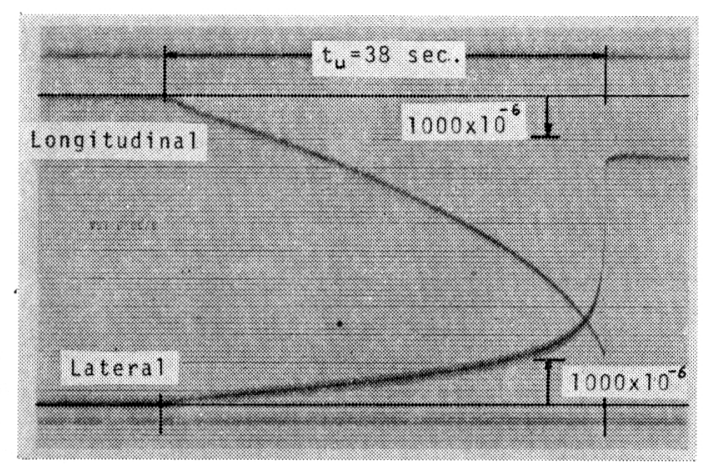

Fig. 1 Strain Time Relationship during Loading (in Air)

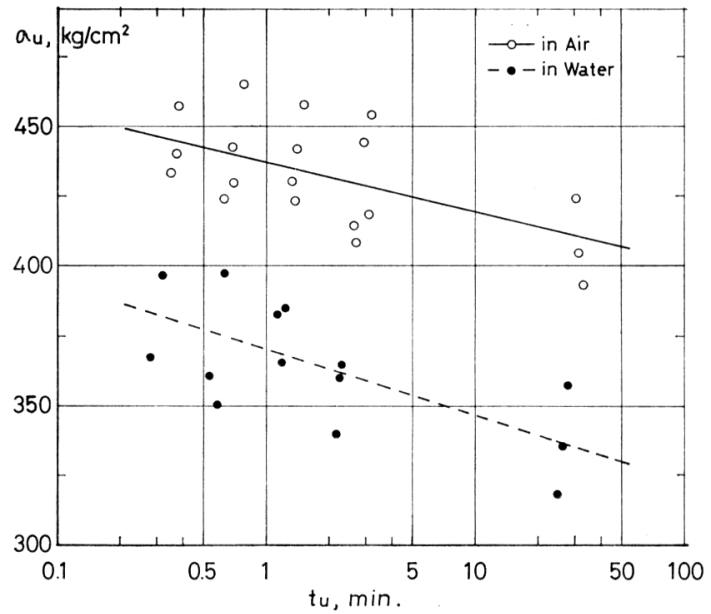

Fig. 2 Relationship between $\sigma_{u}$ and $t_{u}$

中の場合を示している，一次多項式を示した場合にはそ の信頼限界の定数部分を, その他の場合には平均值と標 準偏差を示した.

Table 6 の式 (1) に関して, 圧縮強度を逆数で表わ し変形すると，

空中 : $\left.1 / \sigma_{u}=\left(2.291+0.098 \log t_{u}\right) \times 10^{-3}\left(\mathrm{~cm}^{2} / \mathrm{kg}\right)\right)$ 水中 : $\left.1 / \sigma_{u}=\left(2.711+0.185 \log t_{u}\right) \times 10^{-3}\left(\mathrm{~cm}^{2} / \mathrm{kg}\right)\right\}$

である.すなわち, 圧縮強度と破壊時間との間には, ガ ラスの破壊に関して Glathart らが得た実験式あるいは Taylor, Eyring, Hodgdon らの速度過程論の立場に立 った理論式 などと同様な関係がある。このような関係 についてはすでに畑野がコンクリートの実験から指摘し ている3).

最大圧縮ひずみ $\left(\varepsilon_{\boldsymbol{f}}\right)$ とヤング係数（静的ヤング係数 $\left.E_{s}\right)$ は, Table 6 の式 (2), (4) に示されるように,

Table 6 Experimental Analysis of Mortar Specimens

\begin{tabular}{|c|c|c|c|c|c|c|c|}
\hline \multicolumn{4}{|c|}{ In the Case of Tests in Air } & \multicolumn{4}{|c|}{ In the Case of Tests in Water } \\
\hline No. & Equations from Experiments & $\begin{array}{l}\text { Conf. } \\
\text { Limit }\end{array}$ & F-Test & No. & Equations from Experiments & $\begin{array}{l}\text { Conf. } \\
\text { Limit }\end{array}$ & F-Test \\
\hline $1-\mathbf{a}$ & $a_{u}=438-17.8 \log t_{u}\left(\mathrm{~kg} / \mathrm{cm}^{2}\right)$ & \pm 6.62 & $14.8>_{99} F_{18}{ }^{1}$ & $1-w$ & $\sigma_{u}=370-23.8 \log t_{u}\left(\mathrm{~kg} / \mathrm{cm}^{2}\right)$ & \pm 9.60 & $13.2>_{99} F_{13}{ }^{1}$ \\
\hline $2-\mathrm{a}$ & $\varepsilon_{f}=3323 \pm 484\left(10^{-6}\right)$ & - & $0.08<{ }_{95} F_{8}{ }^{1}$ & $2-w$ & $\varepsilon_{f}=2513 \pm 432\left(10^{-6}\right)$ & - & $0.10<{ }_{95} F_{8}{ }^{1}$ \\
\hline $3-\mathbf{a}$ & $t_{u}=382\left(\dot{\sigma}_{n}\right)^{-0.942}(\mathrm{sec})$ & \pm 0.170 & $76.2>_{99} F_{8}{ }^{1}$ & $3-w$ & $t_{u}=304\left(\dot{\sigma}_{n}\right)^{-0.980}(\mathrm{sec})$ & \pm 0.182 & $63.5>_{99} F_{8}{ }^{1}$ \\
\hline $4-\mathrm{a}$ & $E_{s}=2.27 \pm 0.18\left(10^{5} \mathrm{~kg} / \mathrm{cm}^{2}\right)$ & - & $2.09<{ }_{95} F_{18}{ }^{1}$ & $4-w$ & $E_{s}=2.24 \pm 0.22\left(10^{5} \mathrm{~kg} / \mathrm{cm}^{2}\right)$ & - & $0.26<_{95} F_{13}{ }^{1}$ \\
\hline $5-\mathbf{a}$ & $\dot{\varepsilon}_{z}=5.18\left(\dot{\sigma}_{n}\right)^{0.962}\left(10^{-6} / \mathrm{sec}\right)$ & \pm 194 & $59.7>_{99} F_{8}{ }^{1}$ & $5-w$ & $\dot{\varepsilon}_{z}=5.23\left(\dot{\sigma}_{n}\right)^{0.823}\left(10^{-6} / \mathrm{sec}\right)$ & \pm 0.229 & $32.2>_{99} F_{8}{ }^{1}$ \\
\hline $6-\mathbf{a}$ & $\dot{\varepsilon}_{r}=1.02\left(\dot{\sigma}_{n}\right)^{1.001}\left(10^{-6} / \mathrm{sec}\right)$ & \pm 0.202 & $59.5>_{99} F_{8}{ }^{1}$ & $6-w$ & $\varepsilon_{r}=1.29\left(\dot{\sigma}_{n}\right)^{0.939}\left(10^{-6} / \mathrm{sec}\right)$ & \pm 0.252 & $31.4>_{99} F_{8}{ }^{1}$ \\
\hline $7-\mathbf{a}$ & $\sigma_{u}=415+0.368\left(10^{6} \dot{\varepsilon}_{z}\right)\left(\mathrm{kg} / \mathrm{cm}^{2}\right)$ & \pm 12.1 & $1.85<{ }_{95} F_{8}{ }^{1}$ & $7-w$ & $\sigma_{u}=352+0.401\left(10^{6} \dot{\varepsilon}_{z}\right)\left(\mathrm{kg} / \mathrm{cm}^{2}\right)$ & \pm 17.0 & $3.75<{ }_{95} F_{8}{ }^{1}$ \\
\hline $8-\mathrm{a}$ & $\varepsilon_{z f}=20.00+22.80 \dot{\sigma}_{n}\left(10^{-6} / \mathrm{sec}\right)$ & \pm 33.1 & $14.8>_{99} F_{8}{ }^{1}$ & 8-w & $\varepsilon_{z f}=48.07+16.65 \dot{\sigma}_{n}\left(10^{-6} / \mathrm{sec}\right)$ & \pm 30.0 & $11.3>_{99} F_{8}{ }^{1}$ \\
\hline $9-\mathbf{a}$ & $K_{s}=1.24 \pm 0.35\left(10^{5} \mathrm{~kg} / \mathrm{cm}^{2}\right)$ & - & $0.35<{ }_{95} F_{18}{ }^{1}$ & $9-w$ & $K_{s}=1.29 \pm 0.27\left(10^{5} \mathrm{~kg} / \mathrm{cm}^{2}\right)$ & - & $0.12<_{95} F_{8}{ }^{1}$ \\
\hline $10-\mathbf{a}$ & $G_{s}=0.894 \pm 0.112\left(10^{5} \mathrm{~kg} / \mathrm{cm}^{2}\right)$ & 一 & $0.41<_{95} F_{18}{ }^{1}$ & $10-w$ & $G_{s}=0.934 \pm 0.106\left(10^{5} \mathrm{~kg} / \mathrm{cm}^{2}\right)$ & - & $0.18<{ }_{95} F_{13}{ }^{1}$ \\
\hline $11-\mathbf{a}$ & $e_{v f}=1135 \pm 132\left(10^{-6}\right)$ & - & $0.01<_{95} F_{8}{ }^{1}$ & $11-w$ & $e_{v f}=830 \pm 316\left(10^{-6}\right)$ & - & $0.41<_{95} F_{8}{ }^{1}$ \\
\hline $12-\mathrm{a}$ & $\sigma_{v} / \sigma_{u}=0.910-0.048 \log \dot{\sigma}_{n}$ & \pm 0.032 & $5.45>_{95} F_{8}{ }^{1}$ & $12-w$ & $\sigma_{v} / \sigma_{u}=0.839 \pm 0.137$ & - & $0.33<{ }_{95} F_{8}{ }^{1}$ \\
\hline $13-\mathbf{a}$ & $\varepsilon_{v} / \varepsilon_{f}=0.697 \pm 0.050$ & - & $0.03_{9}<{ }_{5} F_{8}{ }^{1}$ & $13-w$ & $\varepsilon_{v} / \varepsilon_{f}=0.600+0.178 \log \dot{\sigma}_{n}$ & \pm 0.137 & $7.58>_{95} F_{8}{ }^{1}$ \\
\hline $14-\mathbf{a}$ & $e_{v}=3.21\left(\dot{\sigma}_{n}\right)^{0.967}\left(10^{-6} / \mathrm{sec}\right)$ & \pm 0.352 & $12.8>_{99} F_{8}{ }^{1}$ & $14-\mathrm{w}$ & $e_{v}=3.11\left(\dot{\sigma}_{n}\right)^{0.951}\left(10^{-6} / \mathrm{sec}\right)$ & \pm 359 & $11.7>_{95} F_{8}{ }^{1}$ \\
\hline $15-\mathbf{a}$ & $\sigma_{m}=142+0.148\left(10^{6} e_{v}\right)\left(\mathrm{kg} / \mathrm{cm}^{2}\right)$ & \pm 4.0 & $1.80<{ }_{95} F_{8}{ }^{1}$ & $15-w$ & $\sigma_{m}=116+0.256\left(10^{8} \dot{\boldsymbol{e}}_{v}\right)\left(\mathrm{kg} / \mathrm{cm}^{2}\right)$ & \pm 4.4 & $3.50<{ }_{95} F_{8}{ }^{1}$ \\
\hline
\end{tabular}

* ${ }_{95} F_{18}{ }^{1}=4.41,{ }_{99} F_{18}{ }^{1}=8.28,{ }_{95} F_{13}{ }^{1}=4.67,{ }_{95} F_{13}{ }^{1}=9.07,{ }_{95} F_{8}{ }^{1}=5.32,{ }_{99} F_{8}{ }^{1}=11.26$ 
破壊時間との間に明膫な相関性が認められない，ところ で,これまでの解析においては破壊時間との関倸に注目 してきたが, Table 6 の式 (3) に示されるように, 破 壊時間は荷重速度 $\left(\dot{\sigma}_{n}\right)$ との間に一定の関係が成立って いるから, 破壊時間を荷重速度に置き換えて考えること もできる.

一方, Spooner ${ }^{4)}$, Rüsch ${ }^{5)}$, Sparks と Menzies ${ }^{6)}$ ら の実験によれば, 荷重速度が最大圧縮ひずみに著しい影 響をおよぼすことが示されている。 また, 烟野31 は破壊 時間とヤング係数との間にも相関性のあることを示して いる.このような傾向は, 上述した筆者の実験結果から は明らかではなかったが, その理由の一つとして, 荷重 速度の変化の範囲が他と比較して狭かったことが考えら れる. 実際に, 荷重速度がきわめて遅い圧縮試験の代わ りに実施したクリープ破壊試験の結果 ${ }^{7)}$ を合わせて考え ると, 荷重速度が小さくなると最大圧縮ひずみは大きく なり, ヤング係数は小さくなるといえる.

圧縮強度とこれに対応する最大圧縮ひずみをプロット すると Fig. 3 に示すとおりである. これをみると, 圧 縮強度および最大圧縮ひずみは, 空中に比較して水中の 方が小さく, それぞれの比率は $85 \%, 76 \%$ である.こ れらの值のばらつきをみると, 水中の方が空中より大き く, 最大圧縮ひずみの方が圧縮強度より大きい. 水中に おける圧縮強度の低下は, Mills ${ }^{8)}$, Cook と Haque ${ }^{9)} ら$ が明らかにした湿潤弱化の現象と類似しているが, 実験 方法が異なっている.すなわち, 彼らは高温乾燥したコ ンクリートを再浸潤した場合の強度低下を明らかにして おり, 筆者らの場合は標準温度で養生した水中に扔ける 実験である.しかしながら, 強度低下の原因について は, 同様に, モルタルあるいはコンクリートの内部に吸 着する水のために, その表面エネルギーが減少すること が考えられる。

\section{2）ひずみ速度}

破壞応力のほぼ $60 \%$ 以下の範囲における軸ひずみ $\left(\varepsilon_{z}\right)$ と横ひずみ $\left(\varepsilon_{r}\right)$ の平均速度 $\left(\dot{\varepsilon}_{z}, \dot{\varepsilon}_{r}\right)$ を実験值か ら求め, 荷重速度に対してプロットすると Fig. 4 に示

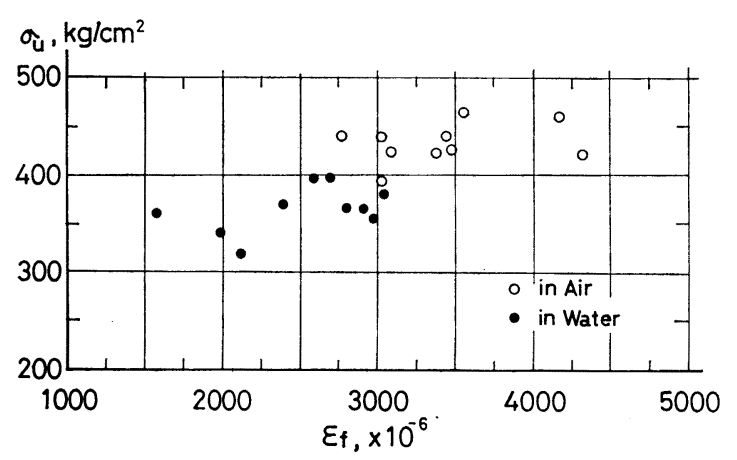

Fig. 3 Relationship between $\sigma_{u}$ and $\varepsilon_{f}$
すとおりである.これからひずみ速度 $\dot{\varepsilon}_{z}, \dot{\varepsilon}_{r}$ は, 荷重速 度との間にほぼ一定の関保が成立つといえるが，これら の実験式は, Table 6 の式 (5), (6) に示すように与 えられる. Fig. 4 の直線の傾きは, 水中の方が空中よ り小さく，横ひずみの方が軸ひずみより小さい，このよ うに，荷重速度がひずみ速度におよぼす影響は，ひずみ の成分あるいは飽和水によって異なっている.

上述した軸ひずみ速度に対して圧縮強度をプロットす ると, Fig. 5 に示されるように, 両者の間にはほぼ直 線によって近似することのできる関倸が成り立っている といえる. すなわち, このような関係を式で表わすと，

Table 6 の式 (7) に示すとおりである. これらの関係

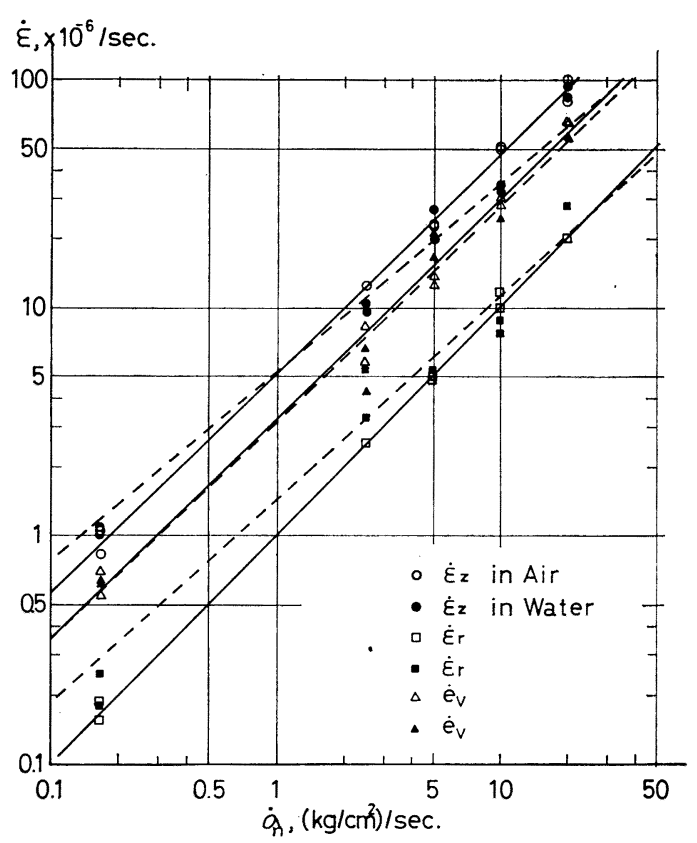

Fig. 4 Relationship between $\dot{\boldsymbol{s}}$ and $\dot{\sigma}_{n}$

$a_{\mathrm{u}} \mathrm{kg} / \mathrm{cm}^{2}$

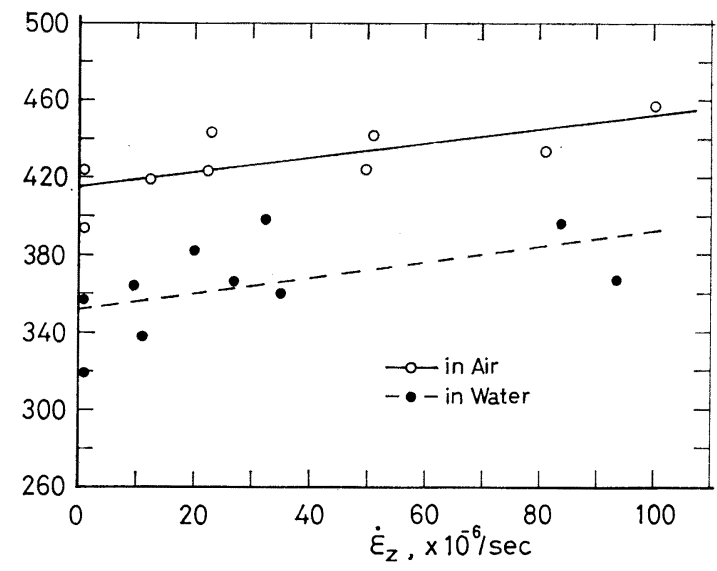

Fig. 5 Relationship between $\sigma_{u}$ and $\dot{\boldsymbol{\varepsilon}}_{z}$ 
は圧縮強度がひずみ速度汇比例することを意味してい る.

一方，破壊応力の 95〜100\% における軸ひずみ速度の 平均值 $\left(\dot{\varepsilon}_{z f}\right)$ を, 荷重速度住してプロットすると,

Fig. 6 に示されるように, 両者の間には Table 6 の式 （8）によって表わされる関係が成り立つことがわかる. すなわち，破壊付近の軸ひずみ速度もまた，Fig. 4 亿 示した破壊応力のほぼ $60 \%$ 以下の範囲におけるひずみ 速度の場合と同様に, 荷重速度との間に一定の関係が成 り立っている.

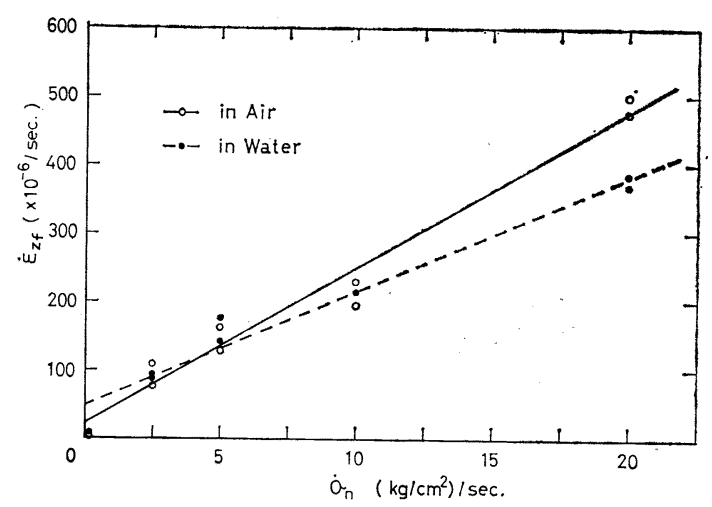

Fig. 6 Relationship between $\dot{\boldsymbol{s}}_{z f}$ and $\dot{\boldsymbol{\sigma}}_{n}$

\section{（2）等方成分と偏差成分に関する応力ーひずみ-時間 の関係}

\section{1）体積変形と形状変形}

一般に, 変形が弾性的であっても粘弾性的であっても 線形重祸合わせを許せるくらいに十分小さく，かつ，材 料が等方性であるならば，応力とひずみは等方成分と偏 差成分に分解することができる、いま, 単軸圧縮応力 $\left(\sigma_{n}\right)$ と軸ひずみ $\left(\varepsilon_{z}\right)$, 横ひずみ $\left(\varepsilon_{r}\right)$ が与えられれば, これらの間には次のような関係が成立つ ${ }^{10)}$.

$$
\left.\begin{array}{ll}
\sigma_{n}=3 K e_{v}, & e_{v}=\varepsilon_{z}+2 \varepsilon_{r} \\
\sigma_{n}=2 G e_{0}, & e_{0}=\varepsilon_{z}-\varepsilon_{r}
\end{array}\right\}
$$$$
\text { ここに, }
$$

$K, G:$ 体積弾性係数, せん断弹性係数 $e_{v}, e_{0}:$ 体積ひずみ, 形状ひずみ

また, ヤング係数 $(E)$ とポアソン比 $(\nu)$ は, パラメ ーター $K, G$ によって次のように表わすことができ る.

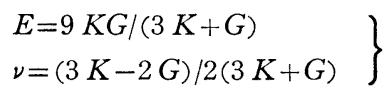

実験結果の等方成分と偏差成分に関する応力ーひずみ 関係（便宜的に応力軸は単軸圧縮応力 $\left(\sigma_{n}\right)$, ひずみ軸は 体積ひずみ $\left(e_{v}\right)$ と形状ひずみ $\left(e_{0}\right)$ を示した）の代表 的一例を Fig. 7 亿示す. 図中で丸印が実験值であり，

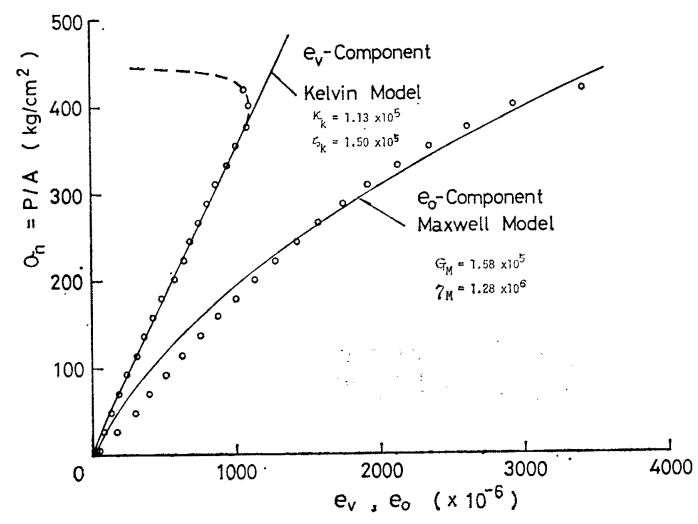

Fig. 7 Comparison between Experimental Datas and Visco-elastic Models

実線は後述する計算值を表わしている．実験值をみる と，体積変形は破壞応力のほぼ $90 \%$ 付近まで直線的で あり，その付近に達すると体積ひずみが膨張側に急に大 きくなる特異点（体積降伏点と便宜的によぶ）を経て膨 張しながら破壊に至っている．一方，形状変形は全体的 に軸ひずみの場合と類似した傾向を示し，体積降伏点付 近から形状ひずみが一層大きくなる傾向がみられる.

このような体積変形における特異点について, Brandtzaeg ${ }^{11}$ はコンクリートの内部組織のゆるみを示すもの であると説明しており, Rüsch ${ }^{5)}$, 横道と角田ら ${ }^{12}$ はク リープ破壊や疲労破壊との関連性を指摘している。 た, Spooner ${ }^{13)}$ は膨張計を考案し,これによる測定值と 電気抵抗線ひずみゲージによる測定值を比較して，両者 に大きな差異がないことを示している.

次に, 体積弹性係数とせん断弹性係数 $\left(K_{s}, G_{s}\right.$, ここ に添字 $s$ は静的を意味する) をヤング係数を求める一般 的方法と同様にして, Fig. 7 に示される応力ーひずみ図 から求める.これらの弾性係数と荷重速度との間には, ヤング倸数の場合と同様に，相関性注認められなかっ た. Table 6 の式 (9),(10)をみると, 空中と水中と の間に大きな差異は認められないといえる.

Table 6 の式 (9)，(10) に示した $K_{s}$ と $G_{s}$ の平均 值を式（4）に代入してヤング俰数とポアソン比を計算 すると, 空中の場合 $E_{s}=2.16 \times 10^{5} \mathrm{~kg} / \mathrm{cm}^{2}, \nu=0.21$, 水 中の場合 $E_{s}=2.26 \times 10^{5} \mathrm{~kg} / \mathrm{cm}^{2}, \nu=0.21$ である.これ らの值を応力ーひずみ図から直接に求めた值と比較する とほぼ一致している.このことから，モルタルの体積変 形と形状変形に関する Hooke の法則は, 比較的応力度 の低い範囲に㧈いて近似的に成り立つものと思われる.

体積降伏点関して検討するならば，体積ひずみ $\left(e_{v f}\right)$ 满重速度によらず空中と水中のそれぞれにおい てほぼ一定であるとみなすことができる (Table 6 の式 (11）参照)．すなわち， $e_{v f}$ をこれに対応する圧縮応力 $\left(\sigma_{v}\right)$ に対してプロットすると Fig. 8 に示すとおりであ 


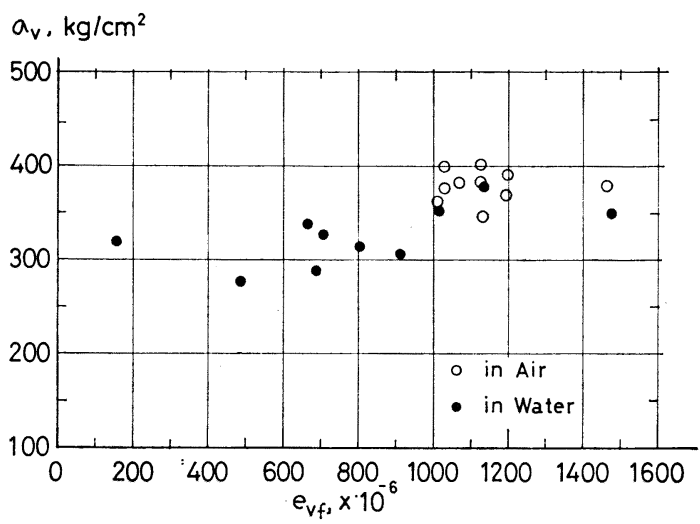

Fig. 8 Relationship between $\sigma_{v}$ and $e_{v f}$

Table 7 Volumetric Yield Point

\begin{tabular}{l|c|c|c}
\hline & $\begin{array}{c}\sigma_{v} \\
\left(\mathrm{~kg} / \mathrm{cm}^{2}\right)\end{array}$ & $\begin{array}{c}e_{v f} \\
\left(\times 10^{-8}\right)\end{array}$ & $\nu_{v}$ \\
\hline in Air & $378 \pm 17$ & $1135 \pm 132$ & $0.259 \pm 0.017$ \\
in Water & $318 \pm 63$ & $830 \pm 316$ & $0.260 \pm 0.045$ \\
\hline Wat./Air & 0.84 & 0.73 & 1.0 \\
\hline
\end{tabular}

る.また, これらの值の平均值と標準偏差を Table 7 に示す. Fig. 8 と Table 7 から $\sigma_{v}$ と $e_{v f}$ の平均值 は空中の方が大きく, そのばらつきは水中の方がかなり 大きいことがわかる. 一方, 体積降伏点に関するポアソ ン比 $\left(\nu_{v}\right)$ をみると, Table 7 に示したように, 空中と 水中との間にほとんど差異がないといえる.

次に, 体積降伏点における圧縮応力 $\left(\sigma_{v}\right)$ および軸ひ ずみ $\left(\varepsilon_{v}\right)$ と，破壊時の圧縮応力 $\left(\sigma_{u}\right)$ および軸ひずみ $\left(\varepsilon_{f}\right)$ との比, すなわち $\sigma_{v} / \sigma_{u}$ および $\varepsilon_{v} / \varepsilon_{f}$ は, 荷重速 度との関係において空中と水中とでそれぞれ異なってい る (Table 6の式 (12), (13) 参照) が, それらの值は, $\sigma_{v} / \sigma_{u}: 76 \sim 97 \%$ (空中および水中), $\varepsilon_{v} / \varepsilon_{f}: 60 \sim 75 \%$ (空中), 50 90\% (水中) であった. 一方, 横道と角田 ら ${ }^{12)}$ によれば, コンクリート (空中) に対して $\sigma_{v} / \sigma_{u}$ は ほぼ 85\% であるとしている.この值は筆者らの值のほ ぼ平均値に相当している.

\section{2) 粘弾性的挙動}

一般に，クリープコンプライアンスを $J(t)$ とすると， 変動応力 $\sigma(t)$ が作用する際の粘弾性体の応力-ひずみ一 時間の関係は, 履歴積分の表現を用いて次のように表わ される(14).

$$
\varepsilon(t)=\sigma(t) J(0)+\int_{0}^{t} \sigma\left(t^{\prime}\right) \frac{d J\left(t-t^{\prime}\right)}{d\left(t-t^{\prime}\right)} d t^{\prime}
$$

いま, 体積変形を Kelvin 体によって, 形状変形を Maxwell 体によって表わし, 作用する応力の履歴を一 定速度の単調増加荷重, すなわち, $t=0$ のとき $\sigma(t)=$ $0, t=t$ のとき $\sigma(t)=\sigma_{1} t / t_{1}$ (ここに, $\sigma_{1}$ は $t=t_{1}$ のとき の応力である）とすれば, 体積変形および形状変形はそ れぞれ次のように表わされる。

$$
\begin{aligned}
& e_{v}(t)=\frac{\sigma_{1}}{q_{0}}\left[1+\frac{q_{1}}{q_{0} t_{1}} 1\left(-e^{q_{0} t_{1} / q_{1}}\right) e^{-q_{0} t / q_{1}}\right] \\
& \quad \text { (対積変形) } \\
& e_{0}(t)=\frac{\sigma_{1}}{q_{1} t_{1}}\left(p_{1} t+\frac{t^{2}}{2}\right) \quad(\text { 形状変形 })
\end{aligned}
$$

ここに,

$q_{0}=3 K_{K}, \quad q_{1}=3 \zeta_{K}$

$K_{K}, \zeta_{K}:$ Kelvin 体の体積弾性係数, 体積粘性係 数

$P_{1}=\eta_{M} / G_{M}, \quad q_{1}=2 \eta_{M}$

$G_{M}, \eta_{M}$ : Maxwell 体のせん断弾性係数, せん断 粘性係数

式（6）による計算值を Fig. 7 に示した実験值と比 較すると体積変形は体積降伏点付近までよく一致してお り，形状変形は十分であるとはいえないが類似した挙動 を示しているといえる.

次に, 体積降伏点に至るまでの体積ひずみ速度の平均 值 $\left(\dot{e}_{v}\right)$ と荷重速度との関係をみると, Fig. 4 に示し たように，軸ひずみおよび横ひずみの場合とほぼ同様な 傾向がみられ，その実験式は Table 6 の式 (14) のよ らに表わされる．この体積ひずみ速度に対して圧縮強度 をプロットすると Fig. 9 に示すとおりである. 両者の 関係は Table 6 の式（15）のように表わされる.ただ し, Table 6 の式 (15) の $\sigma_{m}$ は平均応力を意味し $\sigma_{m}=\sigma_{n} / 3$ である. これは Table 6 の式 (7) と同じ形 をしているが, M. Reiner が導いている Kelvin 体の破 損時の応力ーひずみ-時間の関係を表わす式 ${ }^{10)}$ と同じ形で あるといえる. ここに，M. Reiner の式は次のようで ある・

$\sigma_{f}=\sigma_{f s}+\zeta_{K} \dot{e}_{v}, \sigma_{f s}=\sqrt{2 E_{f} K_{K}}$

ここに,

$\sigma_{f}:$ 破壊応力 (等方成分)

$\sigma_{f s}:$ 静的負荷時 $\left(\dot{e}_{v}=0\right)$ の破壊応力

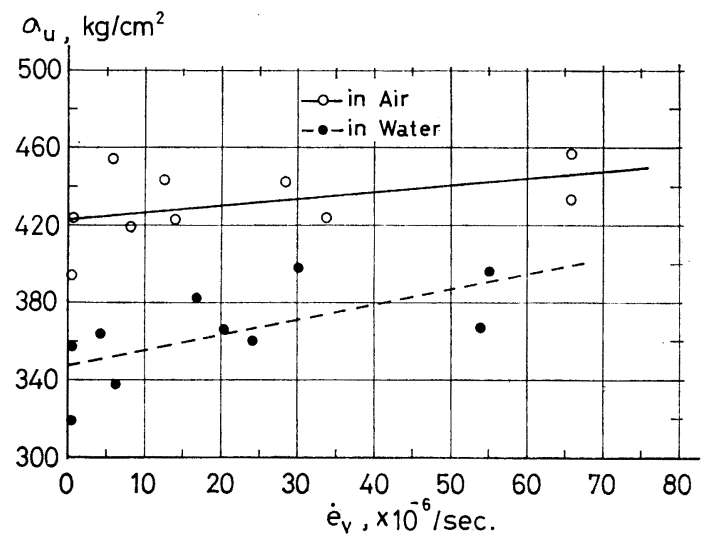

Fig. 9 Relationship between $\sigma_{u}$ and $\dot{e}_{v}$ 
$E_{f}:$ 破壊に抗するひずみエネルギー

式（7）の記号は体積変形に関するものを示している が, 必要ならば他の変形成分に関する記号によって表わ すことができる、筆者らの実験式 (Table 6 の式 (15)) と式 $(7)$ を比較すると, 体積粘性倸数 $\left(\zeta_{K}\right)$ は空中と 水中に関しそれぞれ $1.48 \times 10^{5}, 2.56 \times 10^{5}\left(\mathrm{~kg} \cdot \mathrm{sec} / \mathrm{cm}^{2}\right)$ のよらに与えられる. $\zeta_{k}$ の大きさは Fig. 9 の直線の 傾きの大きさを表わすものであるが，これから，水中の 方が空中に比較して $\zeta_{k}$ が大きくひずみ速度の影響を大 きく受けることがわかる。

\section{（3）繰り返し荷重下の応力ーひずみ履歴}

繰り返し圧縮荷重下の軸ひずみと横ひずみの履歴を才 ッシログラフに再生した一例を Fig. 10 に示寸。また， 繰り返し試験の条件と結果の一部を Table 8 に示す. ここに, 周期 $(T)$, 空中あるいは水中の区別, 振幅, 疲 労破壊の起きた繰り返し回数 (疲労寿命 $N_{f}$ ), 圧縮強 度 $\left(\sigma_{f}\right.$ 注疲労破壊の起きた応力度を示し, 他方は 100 回を越えても疲労破壊を生じなかったため荷重を上げて 破壊させた時の忘力度を示している) 右端に示した記号 は図中において試験条件の区別をするために用いる.

Table 8 の供試体番号 20 の場合を例に取って応力ひずみ関係の履歴を図示すると，Fig. 11 に示すとおり である、ここに，(a) は単軸圧縮応力-軸ひずみの関倸 $\left(\sigma_{n}-\varepsilon_{z}\right)$, (b) は体積変形 $\left(\sigma_{n}-e_{v}\right)$, (c) 汧状変形

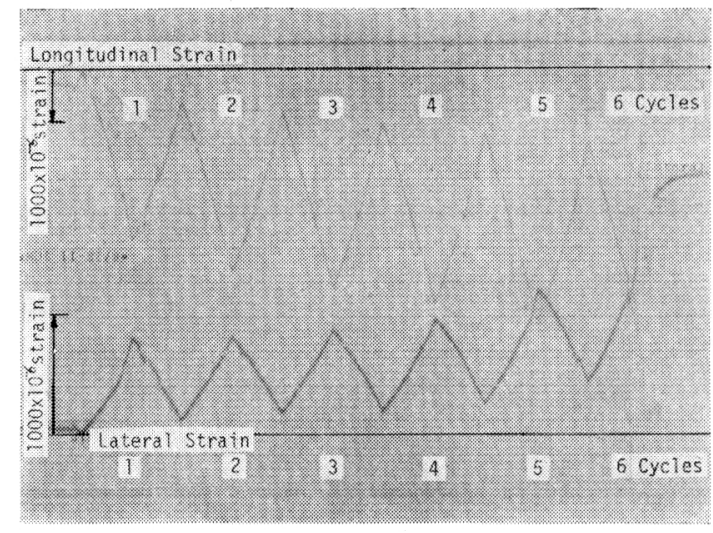

Fig. 10 Description of Longitudinal and Lateral Strain during Cycle Load

$\left(\sigma_{n}-e_{0}\right)$, ただし (b), (c) の縦軸には便宜的に単軸圧縮 応力をとっている. これらの図を比較すると, 形状変形 に関する履歷図は軸ひずみの場合と同様な傾向を示して いるが，体積変形に関する履歴図はこれらとは異なって おり，3サイクル以後は体積ひずみが膨張側に増大する 特異現象がみられる.この現象は静的圧縮荷重下にみら れた特異点と同様な性質のものであると考えられる. 次 に, このような履歴特性についてさらに検討してみる.

\section{1) ヤング係数と体積弾性係数}

1 サイクルのヤング係数 $\left(E_{d_{1}}=E_{s}\right)$ で任意のサイク ルのヤング係数 $\left(E_{d_{N}}\right)$ を割った值 $\left(E_{d_{N}} / E_{d_{1}}\right)$ を縦軸

Table 8 Details of Fatigue Test

\begin{tabular}{|c|c|c|c|c|c|c|c|c|}
\hline \multirow{2}{*}{$\begin{array}{c}\text { Specimens } \\
\text { No. }\end{array}$} & \multicolumn{2}{|c|}{ Test Condition } & \multicolumn{2}{|c|}{ Load Amplitude $\left(\mathrm{kg} / \mathrm{cm}^{2}\right)$} & \multirow{2}{*}{$\begin{array}{c}\text { Cycles to } \\
\text { Failure } \\
N_{f}\end{array}$} & \multicolumn{2}{|c|}{ Comp-Strength $\left(\mathrm{kg} / \mathrm{cm}^{2}\right)$} & \multirow[b]{2}{*}{ Symbols } \\
\hline & $\begin{array}{c}\text { minute } \\
\text { cycle } \\
T \\
\end{array}$ & Air or Water & Lower Limit & Upper Limit & & Fail $\sigma_{f}$ & $\operatorname{did}_{\mathbf{x}}^{\pi}$ not Fail & \\
\hline 1 & 4 & Air & 33 & 331 & 95 & 331 & & 0 \\
\hline 2 & 4 & Air & 33 & 331 & (683) & & 427 & $\mathrm{O}$ \\
\hline 3 & 4 & Water & 33 & 331 & 20 & 306 & & 0 \\
\hline 4 & 4 & Water & 33 & 331 & 22 & 327 & & - \\
\hline 5 & 2 & Air & 33 & 331 & (635) & & 432 & 0 \\
\hline 6 & 2 & Air & 33 & 331 & $(200)$ & & 415 & $\mathrm{O}$ \\
\hline 7 & 2 & Water & 33 & 331 & 31 & 331 & & - \\
\hline 8 & 2 & Water & 33 & 331 & 35 & 329 & & 0 \\
\hline 9 & 1 & Air & 33 & 331 & $(556)$ & & 455 & $\triangle$ \\
\hline 10 & 1 & Air & 33 & 331 & $(754)$ & & 407 & $\triangle$ \\
\hline 11 & 1 & Water & 33 & 331 & 9 & 319 & & $\Delta$ \\
\hline 12 & 1 & Water & 33 & 331 & 19 & 331 & & $\boldsymbol{\Delta}$ \\
\hline 13 & 1 & Water & 33 & 331 & 6 & 329 & & $\boldsymbol{\Delta}$ \\
\hline 14 & 0.5 & Air & 33 & 331 & $(794)$ & & 442 & $\nabla$ \\
\hline 15 & 0.5 & Air & 33 & 331 & (794) & & 424 & $\nabla$ \\
\hline 16 & 0.5 & Water & 33 & 331 & 5 & 329 & & $\nabla$ \\
\hline 17 & 0.5 & Water & 33 & 331 & 3 & 322 & & $\nabla$ \\
\hline 18 & 0.5 & Water & 33 & 331 & 5 & 255 & & $\nabla$ \\
\hline 19 & 2.25 & Air & 33 & 369 & 31 & 338 & & $\square$ \\
\hline 20 & 2.25 & Air & 33 & 369 & 21 & 345 & & $\square$ \\
\hline 21 & 2.25 & Air & 33 & 369 & 10 & 368 & & $\square$ \\
\hline 22 & 2.25 & Air & 33 & 369 & 1 & 358 & & $\square$ \\
\hline 23 & 2 & Water & 33 & 331 & 13 & 310 & & 圆 \\
\hline 24 & 2 & Water & 33 & 331 & 7 & 312 & & 回 \\
\hline 25 & 2 & Water & 33 & 331 & 1 & 259 & & \\
\hline
\end{tabular}




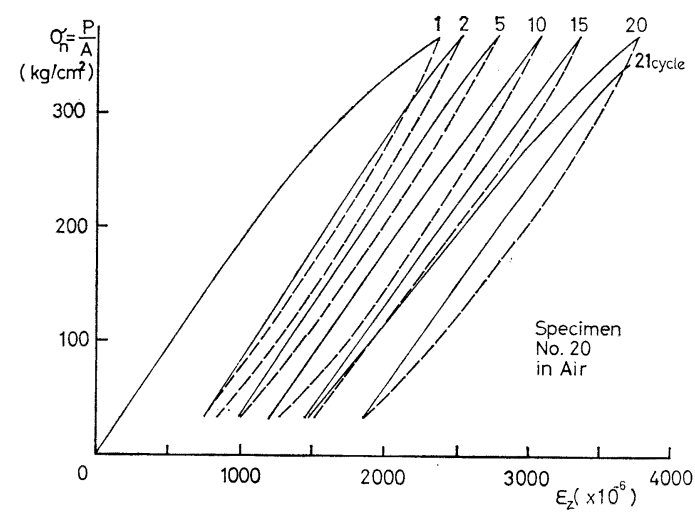

(a) $\sigma_{n}-\varepsilon_{z}$ diagram

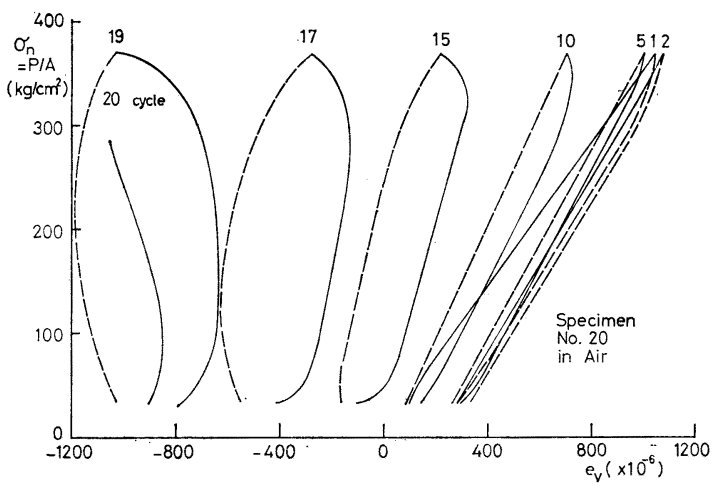

(b) $\sigma_{n}-e_{v}$ diagram

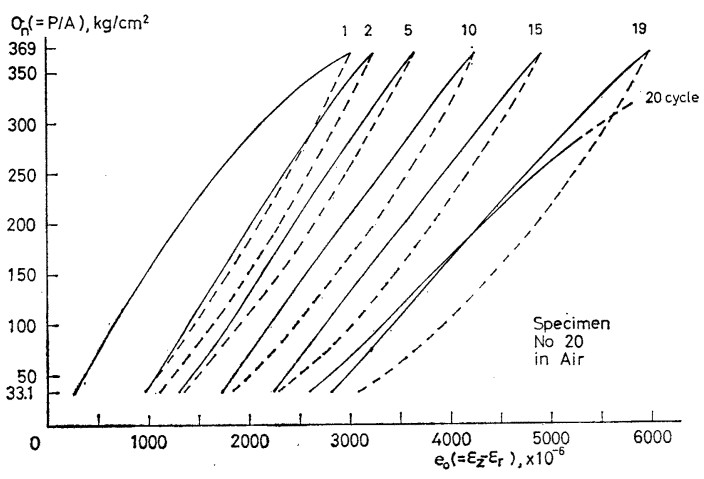

(c) $\sigma_{n}-e_{0}$ diagram

Fig. 11

に, サイクル比 $\left(N / N_{f}\right)$ を横軸にとって, 実験值をプ ロットすると Fig. 12 に示すよらな図が得られる.こ こに, 添字 $d$ は繰り返し試験（あるいは動的）を意味 する. Fig. 12 に示した実験值は Table 8 のうちの一 部の供試体に関するもので, No. 1, 20 (空中), No. 3, 23 (水中) の合計 4 つの場合である. 疲労破壊に至るま でのヤング係数の変化を表わす曲線形は, 水中の方が空 中に比較して疲労寿命の前半期における低下が著しい. しかしながら, 疲労破壊直前のヤング 係数は空中で

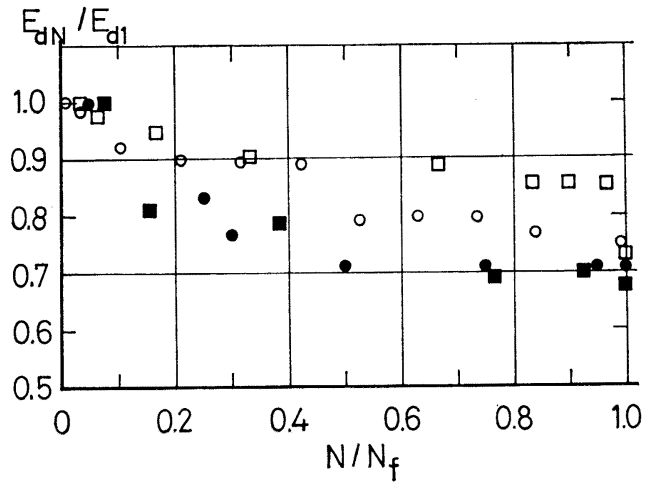

Fig. 12 Relationship between $E_{d N} / E_{d_{1}}$ and $N / N_{f}$

$1.60 \times 10^{5} \mathrm{~kg} / \mathrm{cm}^{2}\left(E_{d_{f}} / E_{d_{1}}=0.71\right)$, 水中で $1.59 \times 10^{5}$ $\mathrm{kg} / \mathrm{cm}^{2}\left(E_{\boldsymbol{d}_{\boldsymbol{f}}} / E_{\boldsymbol{d}_{1}}=0.73\right)$ であり, 両環境における差異 はほとんどないといえる.

繰り返し荷重によるヤング係数の変化について,これ までに高周期の場合に 50〜60\% に低下することが示さ れており, 低周期の場合には, 都築と成岡が軽量コンク リートに対し 90〜93\% に低下することを示している ${ }^{15)}$. これらの実験結果と筆者らのものを比較すると, 実験条 件の相違のために断定することは避けなければならない が, 高周期の場合に比較して低周期の場合の方がヤング 係数の低下が少ないようである。

次に, 体積弾性係数に関して, ひずみ軸に対する角度 $\theta=\tan ^{-1}\left(K_{d_{N}} \times 10^{-6}\right)$ を縦軸に, 横軸にサイクル数をと って図示すると Fig. 13 に示すとおりである. 空中の 場合には，体積弾性係数は疲労破壊に近つくと $\theta$ が $90^{\circ}$ 以上になって, $K_{d}$ が負の值になってしまう. 水中の場 合には空中に比較して $\theta$ あるいは $K_{d}$ の変化は小さい ようである。

2）軸ひずみ, ポアソン比, 体積ひずみ

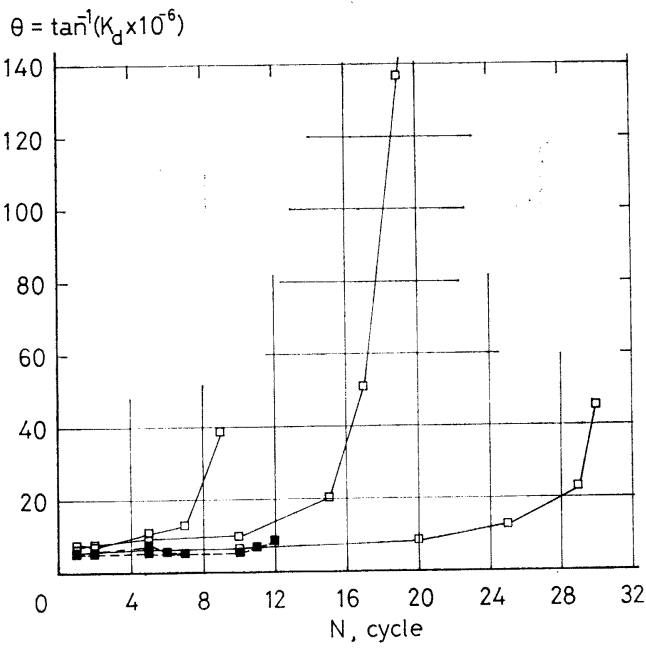

Fig. 13 Relationship between $\theta$ and $N$ 


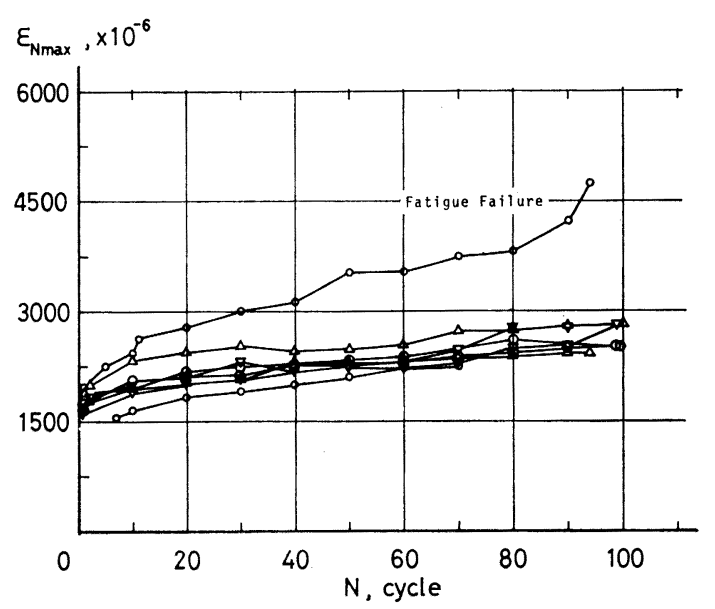

(a)

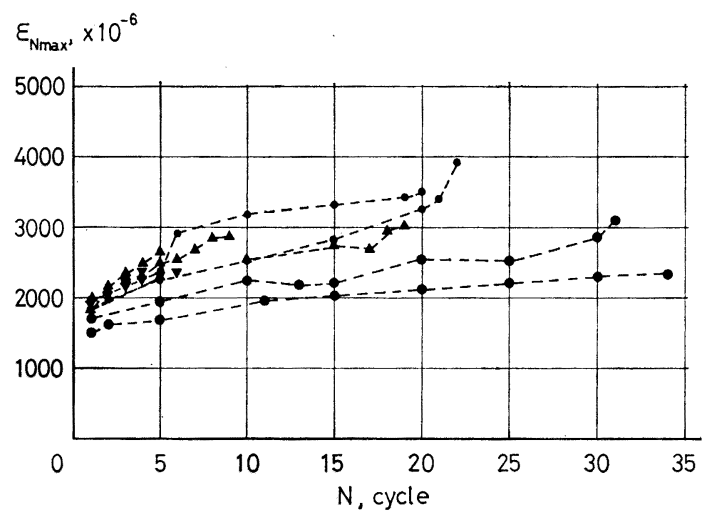

(b)

Fig. 14 Relationship between $\varepsilon_{N_{\max }}$ and $N$

各サイクルにおける軸ひずみの最大值 $\left(\varepsilon_{N \max }\right)$ をサ イクル数に対してプロットすると, Fig. 14 に示すとお りである. Fig. 14(a) は荷重振幅 (A) $33 \sim 331 \mathrm{~kg} / \mathrm{cm}^{2}$ (80\%) の場合であるが，疲労破壊を生じた場合（No. 1）をみると, この曲線形はクリープ破壊曲線 と類似し ており，疲労破壊を生じなかった他の場合には，100サ イクル付近でほぼ一定值 $\left(2400 \times 10^{-6}\right)$ に集まる傾向を 示している. 一方, Fig. 14 (b) 渮重振幅 $(A)$ の水 中の場合 (90\%) であるが，すべて疲労破壊を生じてお り疲労破壊時の軸ひずみの最大值の比較が可能である. すなわち，軸ひずみの最大值は荷重の周期が大きくなる （荷重速度が小さくなる）と大きくなる傾向を示し，こ れを式で表わすと次のとおりである.

$\varepsilon_{f}=2712+1157 \log , T \times 10^{-6}$

$0.5 \leqq T \leqq 4 \mathrm{~min} /$ cycle

疲労破壊時の軸ひずみの最大值は, 荷重振幅 $(B) 33$ $\sim 369 \mathrm{~kg} / \mathrm{cm}^{2}$ の空中の場合 $(90 \%)$ に $3579 \pm 283$, $\times 10^{-6}$ であり,これは 1 サイクルのほぼ 1.6 倍, 静的 破壊時のほぼ 1.1 倍である. 水中の場合について平均值
を求めると $2773 \times 10^{-6}$ であり, これは 1 サイクルのほ ぼ 1.6 倍, 静的破壊時のほぼ 1.1 倍である. また, 水 中の疲労破壊時の軸ひずみの最大值 は空中のほぼ $78 \%$ であるが，これは静的破壊時の水中と空中の最大值の比 (76\%) と比較してほとんど差異はないといえる.

一方, 畑野 ${ }^{16)}$, 都築と成岡 ${ }^{15)}$ らは静的破壊と疲労破壊 における軸ひずみの最大值はほぼ一致するとしている. しかしながら，筆者らの実験結果からは静的破壊よりも 疲労破壊の方が軸ひずみの最大值が大きく，また，荷重 速度が小さい（あるいは荷重周期が大きい）ほどその值 は大きいといえる.すなわち，一般に破壊に至るまでに 荷重を受けている時間が長くなるほど，破壊時のひずみ が大きくなると考えられる．このことはすでに述べたよ らに, Spooner ${ }^{4)}$, Rüsch $^{5)}$, Sparks と Menzies ${ }^{6)} ら の$ 実験結果とも一致した傾向であると思われる.

次に, 各サイクルにおける圧縮強度の $40 \%$ 付近のポ アソン比 $\left(\nu_{d}\right)$ のサイクル数に対する変化をみると,

Fig. 15 に示すとおりである. Fig. 15 は空中の振幅 (A) の場合 (80\%) であるが，100 サイクルをこえても 疲労破壊を生じなかった場合にはポアソン比の変化はほ とんどみられなかったのに対して, 疲労破壊に近づくと ポアソン比の変化が著しくなることを示している. この ようなポアソン比の変化は，横ひずみに注目することが 疲労破壊に近づいたことすなわち疲労寿命を知る目安を 与えてくれることを示していると思われる.

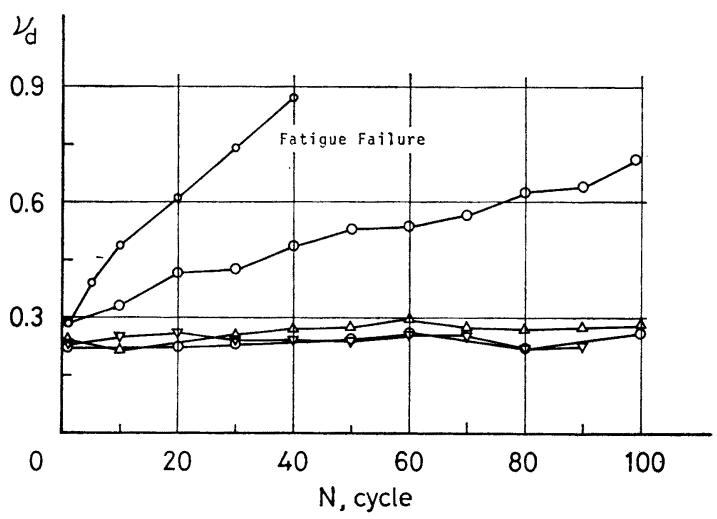

Fig. 15 Relationship betwee $\nu_{d}$ and $N$

各サイクルにおける体積ひずみの最大值 $\left(e_{V N \text { max }}\right)$ を サイクル比に対してプロットすると, Fig. 16 に示すよ らに空中と水中との間において異なった曲線が得られ る. Fig. 16 には疲労破壊を生じた供試体の一部の場合 を示しでいるが, これから, 空中の場合には体積ひずみ が最大值に達する時期は水中の場合より早い（疲労寿命 に対する比）ことがわかる. Fig. 11 と Fig. 16 に みられる変形の特異点（静的破壊の場合と同様に体積 降伏点とよぶ）に関する体積ひずみ $\left(e_{v f}\right)$, 軸ひずみ 


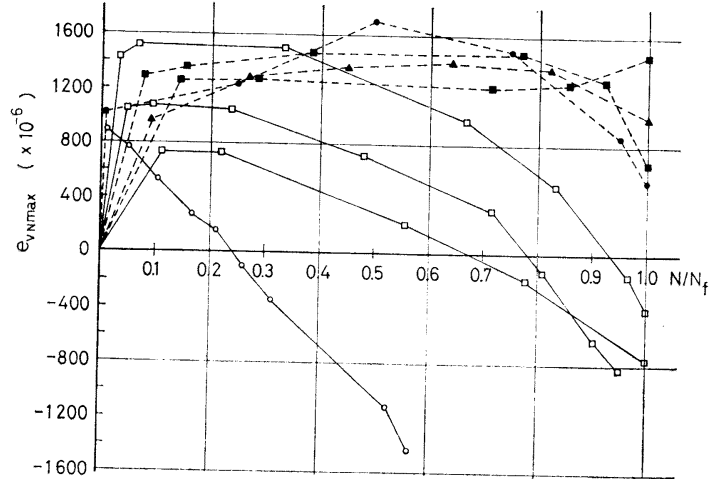

Fig. 16 Relationship between $e_{v N_{\max }}$ and $N / N_{f}$

Table 9 Volumetric Yoield Point

\begin{tabular}{c|c|c|c}
\hline & in Air & in Water & $W / A$ \\
\hline$e_{v f}\left(\times 10^{-6}\right)$ & $1244 \pm 220$ & $\begin{array}{c}1069 \pm 355 \\
(1.3)\end{array}$ & 0.86 \\
$\varepsilon_{v} \quad\left(\times 10^{-6}\right)$ & $\begin{array}{c}2277 \pm 414 \\
(1.0)\end{array}$ & $\begin{array}{c}2221 \pm 443 \\
(1.0)\end{array}$ & 1.00 \\
$\nu_{v}$ & $\begin{array}{c}0.243 \pm 0.026 \\
(1.0)\end{array}$ & $\begin{array}{c}0.265 \pm 0.043 \\
(1.0)\end{array}$ & 1.10 \\
\hline
\end{tabular}

$\left(\varepsilon_{v}\right)$, ポアソン比 $\left(\nu_{v}\right)$ は, Table 9 に示すような值を とり, 静的破壊の場合と比較すると（）中の数字によ って示されるように $e_{v f}$ の水中の場合を除いてあまり差 異はないといえる. 一方, 体積降伏点が現われるサイク ル数 $\left(N_{v}\right)$ 注疲労寿命 $\left(N_{f}\right)$ に対してほぼ一定である とみなされ，その比は空中の場合 $0.126 \pm 0.003$, 水中 の場合 $0.421 \pm 0.283$ である. したがって, 比較的早い 時期に現われる体積降伏点を利用して途中打切りデータ の疲労寿命を推定することが可能であると考えられる. このようにして推定した疲労寿命を Table 8 に示した. これらの疲労寿命と荷重周期との関係をみると, 疲労寿 命は荷重周期が大きくなると短くなる傾向がみられる. このことは Sparks と Menzies ${ }^{6)}$, 畑野ら ${ }^{17)}$ の実験結果 と同様な傾向であると思われる.

\section{3）超音波伝播速度}

一般に, 物質中を通過する音波（縦波の弾性波）の速 度 $(v)$ と音吸収係数（減衰定数 $\alpha$ ) は, 物質の密度 $(\rho)$, 体積弾性係数 $(K)$, せん断弾性係数 $(G)$, 体積粘 性係数 $\left(\zeta_{s}\right)$, せん断粘性係数 $(\eta)$, 音の振動数 $(\omega)$ な どによって，それぞれ次のように表わされる ${ }^{18)}$.

$$
\left.\begin{array}{c}
v=\sqrt{\left(K+\frac{4}{3} G\right) / \rho} \\
\alpha=\frac{2 \pi^{2} \omega^{2}}{\rho v^{3}}\left(\zeta_{s}+\frac{4}{3} \eta\right)
\end{array}\right\}
$$

式 (9) に筆者らが実験的に得た物理定数 $\left(K, G, \zeta_{s}\right.$, $\eta ）$ を代入して, $v$ と $\alpha$ を計算すると, Table 10 に示 すように, 空中と水中の両者に㧍いて, 超音波伝播速度 測定器によって直接測定した值 (Fig. 17 において $\varepsilon_{z r}=$ 0 の時のvの值）よりやや小さいが，比較的良く一致し ている. 一方, 空中と水中とを比較すると, $v$ は水中の 方が大きいが，これは音波の速度が空中より水中におい て速いためであり，また， ※は水中の方が大きいが，こ れは粘性係数 $\left(\zeta_{s}, \eta\right)$ が空中より水中において大きいと いら実験結果と一致するものであると考えられる.

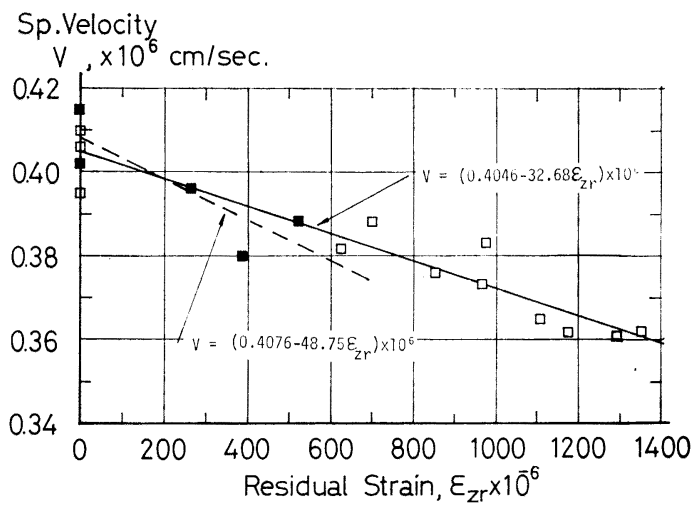

Fig. 17 Relationship between $v$ and $\varepsilon_{z r}$

Sp.Velocity

$\mathrm{V}, \times 10^{6} \mathrm{~cm} / \mathrm{sec}$

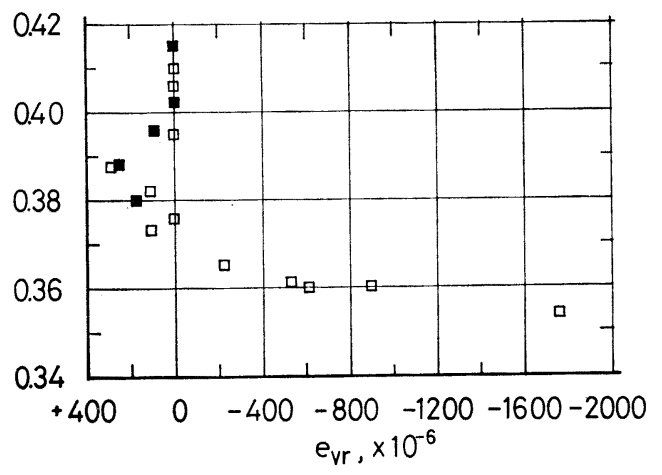

Fig. 18 Relationship between $v$ and $e_{v r}$

次に，任意のサイクルにおいて荷重を除荷して測定し た超音波伝播速度とこれに対応する残留ひずみ $\left(\varepsilon_{z r}\right.$, $\left.e_{r r}\right)$ とをプロットすると， Fig. 17, 18 に示すとおりで ある.ここに, プロットした值は Table 8 の供試体 No. 19〜25に関するものである. 軸ひずみの場合には,

Table 10 Material Constants and Coefficients

\begin{tabular}{|c|c|c|c|c|c|c|c|c|}
\hline & $\begin{array}{c}\text { Bulk } \\
\text { Modulus, } K \\
\left(\mathrm{~kg} / \mathrm{cm}^{2}\right)\end{array}$ & $\begin{array}{c}\text { Shear } \\
\text { Modulus, } G \\
\left(\mathrm{~kg} / \mathrm{cm}^{2}\right)\end{array}$ & $\begin{array}{c}\text { Density } \\
\rho \\
\left(\mathrm{g} \cdot \mathrm{s} / \mathrm{cm}^{2}\right) \\
\end{array}$ & $\begin{array}{c}\text { Frequency of } \\
\text { Super Sonic } \omega \\
\text { (c/s) }\end{array}$ & $\begin{array}{c}\text { Velocity of } \\
\text { Super Sonic } v \\
(\mathrm{~cm} / \mathrm{s})\end{array}$ & $\begin{array}{c}\text { Solid Volume } \\
\text { Viscosity, } \zeta_{s} \\
\left(\mathrm{~kg} \cdot \mathrm{s} / \mathrm{cm}^{2}\right) \\
\end{array}$ & $\begin{array}{l}\text { Coefficient of } \\
\text { Shear } \\
\text { Viscosity, } \eta\end{array}$ & $\begin{array}{l}\text { Coefficient of } \\
\text { Sonic } \\
\text { Absorption, } \alpha\end{array}$ \\
\hline in $\mathrm{Air}$ & $1.24 \times 10^{5}$ & $0.915 \times 10^{5}$ & $2.19 \times 10^{3}$ & $50 \times 10^{3}$ & $3.99 \times 10^{5}$ & $3.44 \times 10^{5}$ & $4.80 \times 10^{5}$ & $3.49 \times 10^{5}$ \\
\hline in Water & $1.29 \times 10^{5}$ & $0.879 \times 10^{5}$ & $2.19 \times 10^{3}$ & $50 \times 10^{3}$ & $4.09 \times 10^{5}$ & $7.69 \times 10^{5}$ & $5.00 \times 10^{5}$ & $4.72 \times 10^{5}$ \\
\hline
\end{tabular}


Fig. 17 にみられるように両者の間に直線的関係が認め られる，一方，体積ひずみの場合には，Fig. 18 にみら れるように $v=0.388$ 付近を境にして $2 つ の$ 異なった曲 線形を示している.これは体積降伏点の存在によるもの であるが，体積ひずみの増加（圧縮側へ）にもかかわら ず，超音波伝播速度が低下していることから，体積降伏 点は Brandtzaeg ${ }^{11)}$ の指摘したようにモルタルの内部組 織のゆるみを表わしていると思われる．また，超音波伝 播速度の低下率は静的破壊の場合にはほぼ $97 \%$ であり， 疲労破壊の場合にはほぼ $89 \%$ である.このことは疲労 破壊時の内部損傷が静的破壊時に比較して大きいという ことを示していると考えられる.

\section{（4）動的強度理論を適用した破損条件}

これまでに示してきたように, 静的荷重および繰り返 し荷重下のモルタルの破壊 は，巨視的な応力-ひずみ， 特にそれらの等方成分と偏差成分に注目することによっ てよく説明することができると思われる．応力ーひずみ の等方成分と偏差成分に注目する見方は Huber-Hencky の静的強度理論と同じ立場に立つものである.ここに， 静的強度理論というのは変形速度の影響を考慮していな いことを意味し, これに対し, 変形速度の影響を考慮し たものを動的強度理論とよんでいる10).

変形速度 (あるいは荷重速度) がモルタルの破壊に関 する応力ーひずみに影響をおよぼすことを考えると, 静 的強度理論によっては十分説明することはできないと思 われる. 一方, 等方成分と偏差成分に関する応力ーひず み-時間の関係は, Kelvin 体と Maxwell 体によってそ れぞれ近似的に表わされることが示されている.したが って, Reiner の動的強度理論 ${ }^{10)}$ を適用することが考え られる. すなわち, 等方成分と偏差成分を Kelvin 体と Mexwell 体によって近似し, 保存仕事の極限值として Huber-Hencky の示した体積変形と形状変形に関するひ ずみエネルギーを考えた破損条件が考えられる．これを 式で表わすと次のとおりである.

$$
\begin{gathered}
\int_{0}^{e_{v} f} K e_{v} d e_{v}=W_{v}-\int_{0}^{t} \zeta_{K}\left(\dot{e}_{v}\right)^{2} d t \geqq E_{v} \\
\quad(\text { 体積変形 }) \\
\int_{0}^{e_{0} f} G e_{0} d e_{0}=W_{0}-\int_{0}^{t} \eta_{M}\left(\dot{e}_{0}\right)^{2} d t \geqq E_{0}
\end{gathered}
$$

ここに,

$W_{v}, W_{0}$ : 体積変形, 形状変形に関する応力仕事 の和

$E_{v}, E_{0}$ : 体積変形, 形状変形に関する破壊に抗 するひずみエネルギー

$e_{v f}, e_{0 f}:$ 体積ひずみ, 形状ひずみの最大值（圧
縮側)

式（10）の右辺第 2 項は散逸仕事を表わし, 供試体に なされた応力仕事の和から散逸仕事を除いた残りの部 分, すなわち保存仕事であるひずみエネルギーが極限值 に達すると破壊に至ることを示している.

式 (10) に従って, 体積降伏点に至るまでの体積ひず みエネルギー $\left(E_{v}\right)$, 破壊に至るまでの形状ひずみエネ ルギー $\left(E_{0}\right)$, 体積降伏点に至るまでの形状ひずみエネ ルギー $\left(E_{0 v}\right)$ を計算すると, それらの平均值は Table 11 に示すとおりである. これをみると, 水中は空中に 比較して静的破壊と疲労破壊の両者においていずれの值 もかなり小さくて, 一方, 疲労破壊の場合は静的破壊に 比較して空中と水中の両者において大きいといえる. 特 に $E_{0 v}$ に関する疲労破壊と静的破壊との比が大きいが， これは疲労破壊においては体積降伏点に達した後から破 壊に至るまでの間の形状変形が, 静的破壊の場合に比較 してかなり大きいことを示していると考えられる. 水中 の $E_{v}, E_{0}$ が空中に比較して小さいのは, 水分の吸着に よってモルタルの表面エネルギーが減少し, そのために 静的破壊応力が低下するのであると考えられるが, 同様 な理由によって水中の疲労寿命が, 同じ荷重振幅の空中 の場合より短くなることについて説明することができる と思われる。

Table 11 Isotropic and Deviatoric Components of Stain Work

\begin{tabular}{l|r|r|r|r|r|r}
\hline & \multicolumn{2}{|c|}{ Static, $\mathbf{g} \cdot \mathrm{cm} / \mathrm{cm}^{8}$} & \multicolumn{2}{|c|}{ Fatique, $\mathrm{g} \cdot \mathrm{cm} / \mathrm{cm}^{3}$} & \multicolumn{2}{|c}{ Fatigue/Static } \\
\cline { 2 - 8 } & in Air & in Water & in Air & in Water & in Air & in Water \\
\hline$E_{v}$ & 74 & 44 & 87 & 73 & 1.18 & 1.66 \\
$E_{0 v}$ & 191 & 133 & 455 & 320 & 2.32 & 3.32 \\
$E_{0}$ & 751 & 616 & 1131 & 666 & 1.51 & 1.08 \\
\hline
\end{tabular}

ところで, Table 11 に示した值は, 荷重速度の範囲 を筆者らの実験より大きくとった場合（たとえばクリー プ破壊に近い状態）には一定值で表わすことはできない ように思われるし, また, モルタル以外の材料の場合に は異なった值をとることが考えられるのであるが，この ような場合についてはさらに検討する必要があると思わ れる.

\section{4. 結 語}

本研究の結論を整理すると次のとおりである.

（1）水中において単軸荷重を受けるモルタルの強度 と変形の性質は, 空中における場合と比較して異なった ところがみられる. 静的試験における単軸圧縮強度と軸 ひずみをみると, いずれも水中の方が空中より小さい. また, 繰り返し試験における疲労寿命をみると, 荷重振 幅の絶対值が等しい場合には水中の方が空中よりかなり 
小さい. これらの結果は, 水中においては水分の吸着に よってモルタルの表面エネルギーが減少することが理由 として考えられる.

（2）圧縮強度, ひずみの最大值, 疲労寿命などにみ られるように, モルタルの強度と変形は荷重速度あるい は時間変数に影響される性質を有している. また, 応力 とひずみの等方成分と偏差成分に注目することによっ て, 静的破壊と疲労破壊について, 両者を関連させて巨 視的に説明することができる. このようなことから，単 軸圧縮荷重下のモルタルの破壊について, 体積変形と形 状変形に関するひずみエネルギーを極限值とみなし, 変 形速度を考慮した破損条件を提案することができると考 えられる。

\section{5. あとがき}

終りに, 本研究にあたって, 終始協力して下さった山 田岩雄 技官, 片山健一, 市川治徳氏をはじめ研究室の 方々に, また, 計算にあたって名古屋大学計算機センタ 一の利用に対し，謝意を表する次第です.

1) 田口玄一: 実験計画法下, 丸善, 昭和 43-10.

2）森 芳郎：レオロジー, 共立出版, 昭和 39-8.

3）畑野 正：コンクリートの破壞強度, ひずみ能力, 弾性 率と破壊時間との関係, 土木学会論文集, 第 73 号, 19613 , pp. 24-7.

4) Spooner D.C. : Stress-strain-time relationships for concrete, Magazine of Concrete Research, Vol. 23, No. 75-76, June-Sept. 1971, pp. 127-131.

5) Rüsch H. : Research towards a General Flexural Theory for Structural Concrete, Jour. ACI, Vol. 57, July 1960 , pp. 1-28.

6) Sparks P.R. and J.B. Menzies : The effect of rate of loading upon the static and fatigue strengths of plain concrete in compression, Magazine of Concrete Research, Vol. 25, No. 83, June 1973, pp. 73-80.

7）市川治德：モルタルの持続荷重下に打ける変形と破壊に 関する実験的研究, 名古屋大学工学部土木工学科, 19752 .

8) Mills R.H. : Strength-maturity Relationships for Concrete which is allowed to dry, RILEM Sym. Haifa, 1960, pp. 1-15.

9) Cook D.J. and M.N. Haque : The effct of Sorption on the Tensile Creep and Strength Reduction of Desicated Concrete, Cement and Concrete Research, Vol. 14, No. 3, 1974, pp. 367-379.

10) Reiner M. : Deformation, Strain and Flow, London, H.K. LEWIS Co. Ltd. 1969. (山田・柳沢訳：レオロ ジーの基礎理論, コロナ社, 昭和 46-6).

11) Brandtzaeg A.: Wirkungs weise umschnurter Betondruckorper Beton und Eisen 31, Jahrgang H. 15, Aug. 1932.

12）横道・角田・鮎田：コンクリートの变形における特異点 について，セメント技年 XXIII, 1969, pp. 231-235.

13) Spooner D.C. : A dilatometer for measuring the volume changes of concrete under load, Magazine of Concrete Research, Vol. 25, No. 84, Sept. 1973, pp. 173-176.

14) Flügge W. : Viscoelasticity, Blaisdell Publishing Company, A Division of Ginn and Company,' 1967 （堀 幸夫訳 : 粘弾性学, 培風館, 昭和 48-11).

15）都築・成岡：低サイクル荷重下に打ける軽量コンクリー トの累積損傷の検討, 土木学会論文報告集, 第 206 号, 1972-10, pp. 125-133.

16）烟野 正：コンクリートの如き脆性体のひずみに立脚し た破壊論, 土木学会論文集, 第 153 号, 1968-5, pp. 31-39.

17）畑野 正：周期的圧縮荷重によるコンクリートの挙動, 土木学会論文集, 第 84 号, 1962-8, pp. 19-26, 周期的 圧縮荷重によるコンクリートの疲労破壊, 土木学会論文 報告集，第 185 号，1971-1，pp. 51-60.

18）中川・神戸：レオロジー，みすず書房，1970-11.

19）小林昭一：コンクリートの破壊機構, コンクリート工学, Vol. 13, No. 2, Feb. 1975, pp. 1-11.

(1974.7.12·受付) 